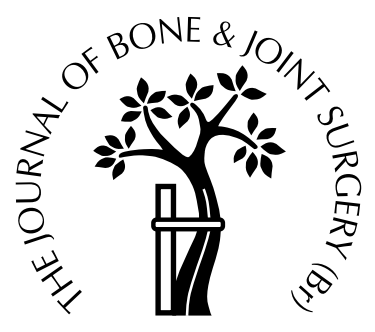

\title{
Immunological changes in patients with primary osteoarthritis of the hip after total joint replacement
}

\author{
Donatella Granchi, Lucia Savarino, Gabriela Ciapetti, Elisabetta Cenni, \\ Roberto Rotini, Michele Mieti, Nicola Baldini, Armando Giunti \\ From the Istituti Ortopedici Rizzoli, Bologna, Italy
}

W e aimed to assess whether the immunological abnormalities which have been observed in patients with loose total hip replacements (THRs) are present in patients with a well-fixed prosthesis.

We examined blood samples from 39 healthy donors, 22 patients before THR and 41 with well-fixed THRs of different types (15 metal-on-metal, 13 metal-onpolyethylene, 13 ceramic-on-ceramic). Before THR, the patients showed a decrease in leukocytes and myeloid cells in comparison with healthy donors, and a prevalence of type-1 $\mathrm{T}$ lymphocytes, which was confirmed by the increase in ratio of interferon- $\gamma$ to interleukin 4. Moreover, patients with metal-on-metal or metal-on-polyethylene implants showed a significant decrease in the number of $\mathrm{T}$ lymphocytes and a significant increase in the serum level of chromium and cobalt, although no significant correlation was observed with the immunological changes. In the ceramic-onceramic group, leukocytes and lymphocyte subsets were not significantly changed, but a significant increase in type- 2 cytokines restored the ratio of interferon- $\gamma$ to interleukin 4 to normal values.

We conclude that abnormalities of the cell-mediated immune response may be present in patients with a wellfixed THR, and that the immunological changes are more evident in those who have at least one metal component in the articular coupling.

J Bone Joint Surg [Br] 2003;85-B:758-64.

Received 31 July 2002; Accepted after revision 14 February 2003

D. Granchi, MD, $\mathrm{PhD}$

L. Savarino, BSc

G. Ciapetti, BSc

E. Cenni, MD

R. Rotini, MD

M. Mieti, MD

N. Baldini, MD

A. Giunti, MD

Laboratorio dei Fisiopatologia degli Impianti Ortopedici, Istituti Ortopedici Rizzoli, via di Barbiano 1/10, 40136 Bologna, Italy.

Correspondence should be sent to Dr D. Granchi.

(C2003 British Editorial Society of Bone and Joint Surgery doi:10.1302/0301-620X.85B5.13729 \$2.00
Total hip replacement (THR) is one of the greatest advances in orthopaedic surgery of the 20th century. It has considerably improved the quality of life of patients affected with osteoarthritis of the hip. In the past, patients between 60 and 75 years of age had been considered to be the best candidates for THR. Over the last decade, however, the age range has broadened to include more elderly, as well as younger individuals. In the latter, the implants may be exposed to greater mechanical stresses over a long period of time and it is therefore important to use materials with the best in vivo durability. ${ }^{1}$ An important long-term requirement is the absence of the systemic effects of wear debris.

Since the longevity of the arthroplasty is affected by the wear of its components, it is important to find new materials and designs with reduced wear debris, which is the main cause of the tissue reaction leading to loosening. ${ }^{2}$ Two hardhard articulations, ceramic-on-ceramic and metal-on-metal, have been developed as alternatives to the ultra-high-molecular-weight polyethylene articulations. The advantages of these combinations are that they generate little debris so that inflammatory reactions and osteolysis are less evident. ${ }^{3-6}$ Nevertheless, corrosion can occur in metal components, releasing ions which invade the local tissues, and enter the circulation. Although some of the biological effects of metal present in the components of hip prostheses are known, the amount of ions needed to produce them is not yet clear. As for all trace elements, a slight increase in their concentration may have a toxic effect. ${ }^{7}$ In vitro tests show that metal ions may be toxic to lymphocytes, and cause cell death or apoptosis. ${ }^{8,9}$ In vitro experiments have shown that stainless steel decreases the production of haemopoietic progenitors with detrimental effects being caused by leaching of metal ions. ${ }^{10}$ Some haematological alteration, such as a reduction in the number of leukocytes and some subpopulations of lymphocytes, has been observed in patients with aseptic loosening of a THR in which the metal component is worn. ${ }^{11}$ Other authors have described examples of the implant causing sensitisation to the metal components in the host. ${ }^{12}$ Mononuclear cells of patients with prosthetic loosening, cultured in the presence of metal ions, show an increase in the expression of activation antigens, and an increase in the release of inflammatory cytokines. ${ }^{13-15}$ Analysis of the tissues retrieved during revision THR has given contradictory results. Some authors have found a low 
Table I. Details of the healthy donors and the 63 patients who underwent THR for osteoarthritis (15 received metal-on-metal, 13 metal-on-polyethylene and 13 ceramic-on-ceramic implants)

\begin{tabular}{llllll}
\hline Number of subjects & $\begin{array}{l}\text { Healthy } \\
\text { controls }\end{array}$ & $\begin{array}{l}\text { Before } \\
\text { surgery }\end{array}$ & $\begin{array}{l}\text { Metal-on- } \\
\text { metal }\end{array}$ & $\begin{array}{l}\text { Metal-on- } \\
\text { polyethylene }\end{array}$ & $\begin{array}{l}\text { Ceramic-on- } \\
\text { ceramic }\end{array}$ \\
\hline $\begin{array}{l}\text { Gender (number) } \\
\quad 39\end{array}$ & 22 & 15 & 13 & 13 \\
$\quad$ M & 15 & 8 & 4 & 3 & 4 \\
$\quad$ F & 24 & 14 & 11 & 11 & 9 \\
Age (years) & & & & $62 \pm 2$ & $62 \pm 3$ \\
$\quad$ Mean \pm SEM & $52 \pm 3$ & $60 \pm 3$ & $50 \pm 2$ & 62 to 79 \\
$\quad$ Range & 40 to 71 & 41 to 74 & 40 to 64 & 45 to 74 & 44 \\
$\quad$ Median & 54 & 59 & 54 & 64 & 62 \\
Follow-up (months) & & & & & $27 \pm 4$ \\
$\quad$ Mean \pm SEM & - & - & $26 \pm 1$ & $27 \pm 1$ & 20 to 30 \\
$\quad$ Range & - & - & 18 to 36 & 18 to 34 & 24 \\
$\quad$ Median & - & - & 25 & 27 &
\end{tabular}

number of quiescent lymphocytes, ${ }^{16}$ while others have found a correlation between the number of T-lymphocytes and macrophages and the cytokine profile and the clinical and radiological grade of loosening. ${ }^{17}$ Most of these studies were carried out on patients with aseptic loosening and it is not yet certain whether the immunological alterations are either involved in the failure of the implant, or related to the presence of the implant or the underlying pathology.

Our main aim was to determine if the immunological changes, previously observed in patients with aseptic loosening, were also present in patients with well-fixed prostheses.

\section{Patients and Methods}

We obtained blood samples from 39 healthy donors and 63 consecutive patients who had primary osteoarthritis of the hip. In 22, the samples were collected the day before surgery so that haematological and immunological changes as a result of anaesthesia could be excluded. A further 41 samples were taken from patients after unilateral primary THR with a follow-up of between 18 and 36 months. In these patients the prostheses were all deemed to be stable, as there were neither symptoms nor radiological evidence of loosening. The patients were divided by prosthetic coupling into three groups. In the 15 who had a metal-on-metal bearing (Metasul; Sulzer Orthopedics Ltd, Winterthur, Switzerland), the acetabular component consisted of a titanium alloy shell (TiAl6Nb7 according to ISO 5832-1), a polyethylene insert reinforced with a Co28Cr6Mo inlay (Protasul-21 WF according to ISO 5832-12) and a Co28Cr6Mo alloy femoral head. The 13 who had a metal-on-polyethylene coupling had the same TiAl6Nb7 cup, polyethylene insert and Co28Cr6Mo alloy femoral head. In the 13 with a ceramicon-ceramic coupling (ANCA-FIT; Wright-Cremascoli Ortho SpA, Milano, Italy), the acetabular component was made of TiAl6Nb7 alloy with a ceramic insert (alumina, Al2O3, ISO 6474) and a ceramic femoral head. All had an uncemented stem made of TiAl6Nb7 alloy. Patients with rheumatoid arthritis, an autoimmune disease or those undergoing immunosuppressive treatment were excluded from the study. The details of the patients are given in Table I.
Analysis of the white blood cells. We collected peripheral venous blood from the patients and the control group and determined the total and differential white blood cell counts to establish the proportion of lymphocyte and myeloid cells. We measured the percentage of $\mathrm{T}$ lymphocytes, B lymphocytes and natural killer cells using fluorescent monoclonal antibodies to the following antigens, CD3 (Tlymphocytes), CD4 (helper/inducer T-lymphocytes), CD8 (cytotoxic suppressor T-lymphocytes), CD19 (B-lymphocytes; Becton-Dickinson, Mountain View, California) and CD16 (natural killer cells; Ortho Diagn. System, Raritan, New Jersey) by using a flow-cytometer equipped with an argon laser (Epics-Elite; Coulter, Hialeah, Florida). We were able to calculate the percentage of fluorescent cells out of 5000 lymphocytes. ${ }^{11}$

Peripheral blood mononuclear cell (PBMC) isolation. After dilution with saline (1:2) the samples underwent FicollHypaque density-gradient centrifugation to separate the mononucleate cells from the erythrocytes and granulocytes. ${ }^{18}$ After collection, washing, centrifugation and resuspension in Aim- $\mathrm{V}$ medium supplemented with L-glutamine (Gibco; Invitrogen, Milan, Italy), the mononuclear suspension $\left(1 \times 10^{5}\right.$ cells $\left./ 100 \mu \mathrm{l}\right)$ was distributed in 96-well culture microplates (Costar, Cambridge, Massachusetts). We added either $100 \mu \mathrm{l}$ of fresh medium in order to control the spontaneous activation of cells (unstimulated PBMC) or the same medium containing phytohaemoagglutinin-P (PHA-P; Sigma, St Louis, Missouri) as a positive control for lymphocyte activation (stimulated PBMC). After incubation for 72 hours at $37^{\circ} \mathrm{C}$ in a $5 \% \mathrm{CO}_{2} / 95 \%$ air atmosphere, the cell cultures were collected and centrifuged. The cells were used for the flow-cytometric analysis of the activation and the cell-free surnatant was frozen at $-20^{\circ} \mathrm{C}$ until the immunoassay.

Lymphocyte activation test. The collected PBMCs were incubated for 20 minutes at $4{ }^{\circ} \mathrm{C}$ with a cocktail of monoclonal antibodies (Fastimmune PE/PerCP; Becton Dickinson, San Jose, California), containing the antibody anti-CD3 conjugated with peridinin-chlorophyl-protein, and the antibody anti-CD69 with phycoerythrin. We were able to determine the proportion of positive CD3/CD69 cells out of 3000 lymphocytes using flow cytometry with an argon laser. The 
Table II. The mean number $/ \mathrm{mm}^{3}$ of leukocytes, myloid cells and lymphocyte subpopulations obtained for the 39 healthy controls, the 22 patients awaiting surgery and the 41 patients 18 to 36 months after THR

\begin{tabular}{|c|c|c|c|c|c|c|}
\hline & Healthy controls & Before surgery & After THR & Metal-on-metal & $\begin{array}{l}\text { Metal-on- } \\
\text { polyethylene }\end{array}$ & $\begin{array}{l}\text { Ceramic-on } \\
\text { ceramic }\end{array}$ \\
\hline Leukocytes & $7061 \pm 264$ & $\begin{array}{l}5987 \pm 466 \\
* p=0.036\end{array}$ & $\begin{array}{l}5647 \pm 217 \\
* p=0.002\end{array}$ & $\begin{array}{l}5429 \pm 264 \\
* \mathrm{p}=0.0002\end{array}$ & $\begin{array}{l}5569 \pm 368 \\
* p=0.002\end{array}$ & $6058 \pm 612$ \\
\hline Myeloid cells & $4575 \pm 230$ & $\begin{array}{l}3734 \pm 332 \\
* \mathrm{p}=0.043\end{array}$ & $\begin{array}{l}3485 \pm 187 \\
* p=0.0005\end{array}$ & $\begin{array}{l}3021 \pm 146 \\
* \mathrm{p}=0.0006\end{array}$ & $\begin{array}{l}3471 \pm 314 \\
* p=0.008\end{array}$ & $3729 \pm 513$ \\
\hline Lymphocytes & $2486 \pm 113$ & $2347 \pm 214$ & $\begin{array}{l}2087 \pm 91 \\
* p=0.007\end{array}$ & $\begin{array}{l}2077 \pm 119 \\
* \mathrm{p}=0.02\end{array}$ & $\begin{array}{l}2002 \pm 144 \\
* p=0.01\end{array}$ & $2204 \pm 229$ \\
\hline $\mathrm{CD} 3$ & $1719 \pm 79$ & $1728 \pm 154$ & $\begin{array}{l}1443 \pm 63 \\
* p=0.0079 \\
\dagger p=0.047\end{array}$ & $\begin{array}{l}1415 \pm 85 \\
* p=0.016\end{array}$ & $\begin{array}{l}1420 \pm 113 \\
* \mathrm{p}=0.036\end{array}$ & $1502 \pm 149$ \\
\hline $\mathrm{CD} 3 / \mathrm{CD} 4$ & $1127 \pm 58$ & $1048 \pm 109$ & $\begin{array}{c}959 \pm 47 \\
* p=0.027\end{array}$ & $\begin{array}{c}934 \pm 57 \\
* p=0.036\end{array}$ & $959 \pm 91$ & $993 \pm 108$ \\
\hline $\mathrm{CD} 3 / \mathrm{CD} 8$ & $666 \pm 41$ & $586 \pm 101$ & $\begin{array}{c}467 \pm 36 \\
* p=0.0006\end{array}$ & $\begin{array}{c}462 \pm 60 \\
* p=0.006\end{array}$ & $\begin{array}{c}458 \pm 74 \\
* p=0.011\end{array}$ & $510 \pm 53$ \\
\hline CD19 & $311 \pm 38$ & $347 \pm 95$ & $239 \pm 15$ & $247 \pm 31$ & $237 \pm 23$ & $227 \pm 24$ \\
\hline CD16 & $302 \pm 22$ & $261 \pm 50$ & $336 \pm 31$ & $358 \pm 43$ & $278 \pm 39$ & $367 \pm 82$ \\
\hline
\end{tabular}

*comparison with healthy controls

†comparison with patients before surgery

activation rate is the ratio between the CD3/CD69 mononuclear cells stimulated by PHA-P and non-stimulated CD3/ CD69 mononuclear cells. ${ }^{19}$

Immunoenzymatic assay of cytokines in the culture supernatants. We used multiple-sandwich enzyme immunoassay to quantitate interleukins IL2, IL4, IL6 and IL10, tumour necrosis factor alpha $(\mathrm{TNF} \alpha)$, interferon gamma $(\mathrm{IFN} \gamma)$, and granulocyte-monocyte colony-stimulating factor (GM-CSF), following the recommended enzymelinked immunoadsorbent assay protocols of the manufacturer (Endogen, Woburn, Massachusetts). Briefly, highly absorbent 96-well microplates were coated with purified antibody aimed at the cytokine being examined. Binding between the cytokine and antibody was detected using anticytokine biotinylated antibody, streptoavidin-peroxidase conjugate and a peroxidase substrate, namely tetramethylbenzidine. The detection limit of the immunoassay was 1 $\mathrm{pg} / \mathrm{ml}$ for IL6 and TNF $\alpha, 6 \mathrm{pg} / \mathrm{ml}$ for IL2, $1 \mathrm{pg} / \mathrm{ml}$ for IL4, $3 \mathrm{pg} / \mathrm{ml}$ for IL10, $2 \mathrm{pg} / \mathrm{ml}$ for IFN $\gamma$ and $2 \mathrm{pg} / \mathrm{ml}$ for GMCSF. Values below the threshold of test sensitivity are considered arbitrarily as $\log ^{-1}$ of the detection limit.

Serum dosage of metal ions. Peripheral blood was collected and centrifuged to separate the serum, which was subdivided and frozen at $-70^{\circ} \mathrm{C}$. When thawed, the serum was again centrifuged to remove any particulate residue. The concentration of chromium, cobalt, molybdenum, aluminium and titanium was measured in each sample by graphite furnace atomic absorption spectrophotometry (GFAAS; Unicam Model Solaar 939 QZ, Cambridge, UK). ${ }^{20}$ The sensitivity of the method was established by using detection limits for sample matrix, i.e. $0.06 \mathrm{ng} / \mathrm{ml}$ for chromium, $0.08 \mathrm{ng} / \mathrm{ml}$ for cobalt, $1.36 \mathrm{ng} / \mathrm{ml}$ for aluminium, $2.91 \mathrm{ng} / \mathrm{ml}$ for titanium and $0.27 \mathrm{ng} / \mathrm{ml}$ for molybdenum. All the subjects having ion levels below the detection levels were adjusted to the detection limit.

Calculations and statistical analysis. For all calculations and statistical analysis we used StatView 5.01 for Windows
(SAS Institute Inc, Cary, North Carolina). The frequency distribution of normal, high and low values of leukocytes, myeloid cells and lymphocyte subpopulations was calculated. The results were expressed as the arithmetic mean \pm SEM. Significant increases in serum levels of ions in all examined groups were evaluated by using the unpaired $t$ test (one tail). The analysis of variance detected the effects of the various articular couplings, and the Bonferroni-Dunn multiple comparison test specific differences between groups. The relationship between serum ion levels and immunological parameters was calculated by Pearson's test, and Fisher's exact test was applied to detect a significant association. Only p values $\leq 0.05$ were considered to be statistically significant.

\section{Results}

In the healthy donors we observed a range of values for myeloid cells and the lymphocytes subsets; total leukocytes (5300 to $9600 / \mathrm{mm}^{3}$ ), granulocytes $\left(2733\right.$ to $7500 / \mathrm{mm}^{3}$ ), lymphocytes (1669 to $4258 / \mathrm{mm}^{3}$ ), CD3 (1239 to 2695/ $\mathrm{mm}^{3}$ ), CD3/CD4 (634 to $1776 / \mathrm{mm}^{3}$ ), CD3/CD8 (347 to $1235 / \mathrm{mm}^{3}$ ), CD19 (133 to $1039 / \mathrm{mm}^{3}$ ) and CD16 (139 to $553 / \mathrm{mm}^{3}$ ).

Before THR many patients had low levels of leukocytes and granulocytes, but two years after the surgery there were fewer with a low level of granulocytes. Changes in the number of lymphocytes and lymphocyte subsets were observed in both groups of patients, but the percentage of patients with a low number of $\mathrm{T}$ lymphocytes tended to increase after THR (data not shown).

The mean values of the white blood cell subsets, leukocytes and myeloid cells of the pre-surgery group were significantly lower than those observed in the healthy controls (Table II). After THR, there were significant differences for most white blood cells with lower counts of leukocytes, myeloid cells, helper/inducer T lymphocytes (CD3/CD4) 
Table III. The serum levels ( $\mathrm{ng} / \mathrm{ml})$ of chromium, cobalt, molybdenum, titanium and aluminium for the 39 healthy controls, the 22 patients awaiting surgery and the 41 patients at the 18- to 36-month follow-up after THR. All values below the detection levels were adjusted to the detection limit $(0.006,0.08,0.27,2.91$ and $1.36 \mathrm{ng} / \mathrm{ml}$ for chromium, cobalt, molybdenum, titanium and aluminium, respectively).

\begin{tabular}{llllll}
\hline & Healthy controls & Before surgery & Metal-on-metal & $\begin{array}{l}\text { Metal-on- } \\
\text { polyethylene }\end{array}$ & $\begin{array}{l}\text { Ceramic-on- } \\
\text { ceramic }\end{array}$ \\
\hline Chromium & $0.30 \pm 0.05$ & $0.29 \pm 0.05$ & $1.54 \pm 0.34 * \dagger$ & $0.79 \pm 0.22^{* \dagger}$ & $0.30 \pm 0.07$ \\
Cobalt & $0.25 \pm 0.05$ & $0.42 \pm 0.1$ & $1.22 \pm 0.26^{* \dagger} \dagger$ & $0.86 \pm 0.24^{* \dagger}$ & $0.18 \pm 0.03$ \\
Molybdenum & n.d. & $0.42 \pm 0.14$ & $0.65 \pm 0.18$ & $0.62 \pm 0.18$ & n.d. \\
Titanium & $3.44 \pm 0.28$ & $2.91 \pm 0$ & $3.19 \pm 0.28$ & $2.91 \pm 0$ & $3.19 \pm 0.24$ \\
Aluminium & $8.24 \pm 1.20$ & $6.92 \pm 0.35$ & $7.07 \pm 1.13$ & $5.14 \pm 0.88$ & $4.96 \pm 1.10$ \\
\hline * $\mathrm{p}=0.005$ comparison with healthy controls & & & \\
$\dagger \mathrm{p}=0.005$ with patients before surgery & & &
\end{tabular}

Table IV. Expression of CD69 antigen (early activation antigen) on CD3 lymphocytes (mean \pm SEM of the percentage of positive CD3/CD69 lymphocytes) for the 39 healthy controls, the 22 patients awaiting THR and the 41 patients at the 18- to 36-month follow-up

\begin{tabular}{lccccc}
\hline & Healthy controls & Before surgery & Metal-on-metal & $\begin{array}{l}\text { Metal-on- } \\
\text { polyethylene }\end{array}$ & $\begin{array}{l}\text { Ceramic-on- } \\
\text { ceramic }\end{array}$ \\
\hline Non-stimulated lymphocytes & $6.8 \pm 1.4$ & $8.4 \pm 3.5$ & $3.7 \pm 0.8$ & $3.8 \pm 0.6$ & $2.5 \pm 0.9$ \\
Lymphocytes stimulated with PHA & $81.2 \pm 4.1$ & $59.1 \pm 12.6$ & $29.2 \pm 5.1$ & $47.8 \pm 5.8$ & $30.7 \pm 5.9$ \\
Activation rate & $13.7 \pm 2$ & $11.7 \pm 2.4$ & $15.3 \pm 5.2$ & $15.34 \pm 2.6$ & $18.8 \pm 4.7$ \\
\hline
\end{tabular}

Table V. Release of cytokines from PBMCs stimulated by PHA for the 39 healthy controls, the 22 patients awaiting surgery and the 41 patients at 18 to 36 months after THR. Data are expressed as $\mathrm{pg} / \mathrm{ml}$ (mean \pm SEM)

\begin{tabular}{|c|c|c|c|c|c|}
\hline & Healthy controls & Before surgery & Metal-on-metal & $\begin{array}{l}\text { Metal-on- } \\
\text { polyethylene }\end{array}$ & $\begin{array}{l}\text { Ceramic-on- } \\
\text { ceramic }\end{array}$ \\
\hline TNF $\alpha$ & $850 \pm 206$ & $1949 \pm 972$ & $570 \pm 115$ & $1120 \pm 475$ & $877 \pm 165$ \\
\hline IL-6 & $3027 \pm 535$ & $3008 \pm 894$ & $2715 \pm 617$ & $2468 \pm 587$ & $3743 \pm 382$ \\
\hline GM-CSF & $963 \pm 145$ & $2335 \pm 869$ & $1977 \pm 507$ & $\begin{array}{l}4207 \pm 368 \\
* p=0.005\end{array}$ & $2347 \pm 358$ \\
\hline IL-2 & $498 \pm 103$ & $\begin{array}{l}1692 \pm 400 \\
* p=0.015\end{array}$ & $817 \pm 200$ & $\begin{array}{l}2498 \pm 623 \\
* p=0.012\end{array}$ & $1633 \pm 810$ \\
\hline $\mathrm{IFN} \gamma$ & $861 \pm 266$ & $1925 \pm 849$ & $1445 \pm 459$ & $\begin{array}{l}2558 \pm 553 \\
* p=0.013\end{array}$ & $\begin{array}{l}2665 \pm 267 \\
* p=0.002\end{array}$ \\
\hline IL-4 & $73 \pm 18$ & $\begin{array}{c}0.1 \pm 0.001 \\
* \mathrm{p}=0.004\end{array}$ & $34 \pm 21$ & $29 \pm 16$ & $\begin{array}{c}402 \pm 55 \\
* \mathrm{p}=0.0002 \\
\dagger \mathrm{p}=0.0001\end{array}$ \\
\hline IL-10 & $434 \pm 141$ & $\begin{array}{c}86 \pm 64 \\
* p=0.04\end{array}$ & $\begin{array}{c}30 \pm 14 \\
* p=0.005\end{array}$ & $\begin{array}{c}59 \pm 33 \\
* p=0.023\end{array}$ & $\begin{array}{c}656 \pm 143 \\
\dagger \mathrm{p}=0.0004\end{array}$ \\
\hline
\end{tabular}

*comparison with healthy controls

†comparison with patients before surgery

and cytotoxic/suppressor $\mathrm{T}$ lymphocytes (CD3/CD8). The total number of $\mathrm{T}$ lymphocytes (CD3) was even lower than that observed in patients before THR (Table II). When divided into three groups according to the features of the prosthetic coupling (Table II) for the metal-on-metal and the metal-on-polyethylene group, there was a significant decrease in the number of leukocytes, myeloid cells, CD3 T lymphocytes and CD3/CD8 T lymphocytes, in comparison with the control group. Moreover, in the metal-on-metal group there was also a decrease in helper/inducer $\mathrm{T}$ lymphocytes (CD3/CD4). We found no variation in B lymphocytes and natural killer cells.

A significant increase in the serum level of chromium and cobalt was observed in patients with metal-on-metal and metal-on-polyethylene couplings compared with the control group and the pre-surgery group (Table III). There was no association between the number of cells and level of circulating ions (data not shown).

Stimulation with PHA-P induced a significant increase in the percentage of positive CD3/CD69 cells in all groups (Table IV). The percentage of positive cells, non-stimulated or stimulated with PHA-P, varied among the groups. Nevertheless, the activation rate was not different between the patients and control group.

Since the percentage of lymphocytes did not differ among the groups, by cultivating fixed quantities of cells, it was possible to verify whether the decrease in the absolute number of $\mathrm{CD} 3$ cells observed in the metal-on-metal and metal-on-polyethylene groups was related to the reduction in a certain subpopulation of T cells, namely type- 1 or type2 lymphocytes. The two subpopulations can be differentiated according to the type of cytokine released. ${ }^{21,22}$ The 


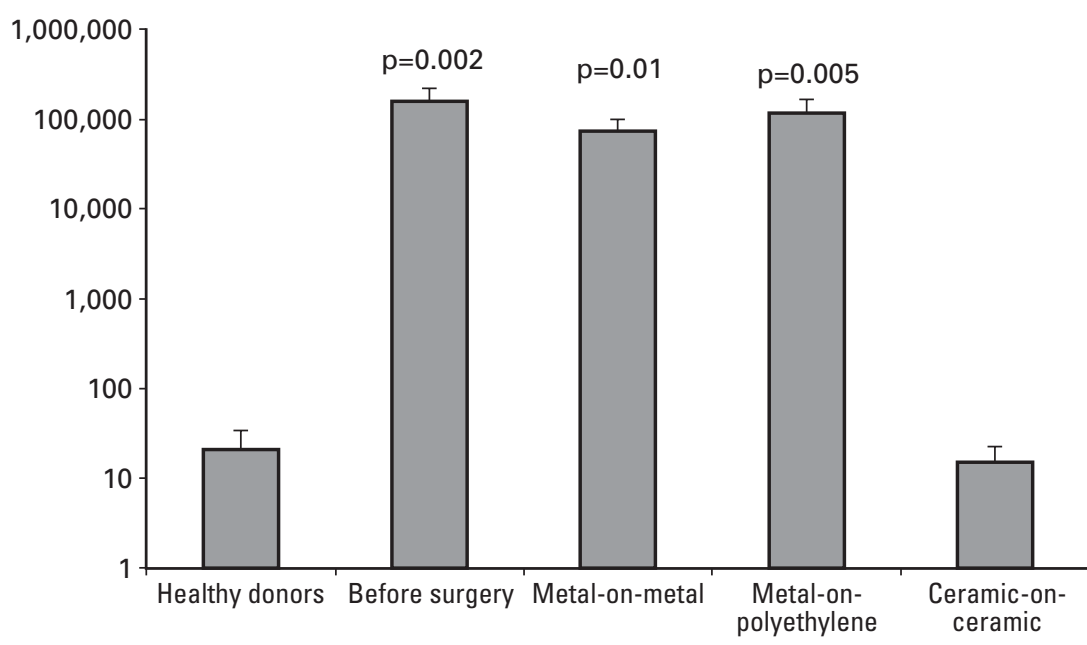

Fig. 1

The relationship between Th1 and Th2 subpopulations based on the pattern of cytokines released by PHA-stimulated PBMC obtained from 39 healthy controls, 22 patients before THR and 41 patients 18 to 36 months after THR. The results are expressed as the mean \pm SEM of the IFN $\gamma$ to IL4 ratio.

supernatants of the cultures of cells stimulated with PHA were assayed and the cytokine levels of patients with a stable prosthesis and patients before surgery were compared with the controls (Table V).

The IL2 release was higher in all groups of patients, but a significant increase was observed only in the pre-surgery and metal-on-polyethylene groups. IFN $\gamma$ correlated with the release of IL2, but was significantly higher in patients with metal-on-polyethylene and ceramic-on-ceramic bearings. The release of IL4 was significantly reduced in the pre-surgery group, whereas in patients with at least one metal articular component, an insignificant decrease was observed. In the ceramic-on-ceramic group, however, there was a significant increase. Even the mean concentration of IL10 had a similar pattern, it being significantly higher in the ceramicon-ceramic group, whereas it was significantly reduced in the other groups.

The IFN $\gamma /$ IL4 ratio, as the index of balance between type- 1 and type- 2 subgroup populations, was significantly higher in the pre-surgery subjects and those with metal-onmetal or metal-on-polyethylene couplings (Fig. 1).

The concentration of inflammatory cytokines IL6 and $\mathrm{TNF} \alpha$ in the supernatants of cultures of mononucleate cells stimulated with PHA-P was highly variable in all groups (Table V), but no differences were observed between the control group, patients with prostheses and the pre-surgery group. The release of GM-CSF was significantly increased in patients with a metal-on-polyethylene bearing.

\section{Discussion}

Our results show that patients with stable prostheses have some haematological and immunological changes. Some, such as the decrease in the number of leukocytes and myeloid cells, are already evident in patients before surgery, but they become more marked in patients with metal-on-metal or metal-on-polyethylene couplings. In particular, the highly significant reduction in the absolute number of leukocytes was not caused by the reduction in a specific cell type, because myeloid cells and lymphocytes were both reduced. T lymphocytes were significantly decreased with the CD8 cytotoxic/suppressor subset being the most involved, and for the metal-on-metal group the CD4 helper/ inducer subset was also decreased. These data show that the haematological and immunological changes which are observed in patients with aseptic loosening were also present in those with a well-fixed prosthesis with at least one metal component of the articular bearing, but not in those with a ceramic-on-ceramic coupling. ${ }^{11}$ These findings raise the possibility that metal ions, such as chromium and cobalt, released from the implant may have a toxic effect on myelopoiesis and the immune system. ${ }^{10,11,23}$

Metal ions such as chromium and cobalt are present physiologically in man and are necessary for carrying out certain functions. Chromium is a trace element which has a role in glucose metabolism and cobalt is an essential micronutrient for mammals. The amount of ions required is not yet clear, but as for all trace elements a slight increase in their concentration may have a toxic effect. Immunological abnormalities were found in groups of patients with at least one metal component of the articular coupling and with high levels of metal ions and therefore, a cause-effect relationship could be supposed. Linear regression analysis did not show a relationship between the concentration of ions and the number of leukocytes, lymphocytes, and relevant subpopulations. The lack of statistical correlation could be due to the biological diversity of the individuals or the small number of subjects in each group. At this time, the assay of circulating ions cannot be considered as being predictive for myelotoxicity or immunotoxicity, but it may be purely 
indicative of damage which should be assessed in each patient by appropriate tests.

From a functional point of view, the lymphocytes of these patients, although reduced in number, were capable of responding to antigenic stimulation. In fact, the activation rate of lymphocytes stimulated by PHA-P was practically the same in all the groups which were examined.

Based on the pattern of cytokines released in the culture supernatant, it was possible to establish whether the quantitative damage to $\mathrm{T}$ lymphocytes was caused by the reduction of some specific subsets. T cells comprise CD3/CD4helper/inducer (Th) and CD3/CD8-cytotoxic/suppressor (Tc) lymphocytes, and each of them exists in two functionally-defined populations: Th1 or Tc1 lymphocytes, producers of IFN $\gamma$ and IL2, and Th2 or Tc2 producers of IL4 and IL10. ${ }^{21,22}$ The balance between type- 1 and type- 2 cells is fundamental for immunoregulation, while imbalance plays a crucial role in determining the phenotype and the severity of various diseases. Type- 1 and type- 2 cytokines have some basic functions in the cell-mediated immune response. IL2 activates the cell-mediated immune response and induces the production of other cytokines, such as IFN $\gamma$ and IL-4, by paracrine and autocrine mechanisms. ${ }^{24}$ IFN $\gamma$ induces the expression of major histocompatibility complex class-II molecules, thereby favouring the presentation of the antigen and stimulating a specific immune response. Furthermore, it induces the activation of monocytes and macrophages and their production of inflammatory cytokines such as $\mathrm{TNF} \alpha$ and IL1. ${ }^{25}$ IL4 acts as a co-stimulator of the differentiation of B lymphocytes, promotes the cytotoxic activity of $\mathrm{T}$ lymphocytes and exerts a powerful inhibitory action on the pro-inflammatory cytokines produced by activated monocytes. ${ }^{26}$ IL10 has a strong inhibitory action on the antigenspecific and anti-inflammatory immune response because it inhibits the production of cytokines by monocytes. ${ }^{27}$

The significant increase in IL2 and IFN $\gamma$ and the IFN- $\gamma /$ IL4 ratio, which we observed in the pre-surgery group, suggests a prevalence in the type- 1 subset, which is also confirmed by the reduction in type- 2 cytokines. These results agree with other authors' findings concerning the involvement of the type- 1 subpopulation in the pathogenesis of osteoarthritis. ${ }^{28-30}$ Activated T lymphocytes, which produce type-1 pattern cytokines, occur in the synovia of patients who have ostoarthritis. Sakkas et al ${ }^{30}$ carried out a study on patients with late-stage osteoarthritis during THR and this series corresponds to our pre-surgery group. T lymphocytes are normally present in chronic inflammation, but Sakkas et $\mathrm{al}^{30}$ added new information concerning the role of $\mathrm{T}$ lymphocytes in degenerative articular disease which can be summarised as follows. T-lymphocyte infiltration of synovia has an oligoclonal repertoire. The lymphocytes are activated locally, as shown by the presence of early and late activation antigens, and the activation is specific, even if the antigen is still unknown. It is mediated by Th1 whereas Th2-type activity is practically absent. Our data show that these alterations are also reflected in peripheral lymphocytes, with an increased production of IFN $\gamma$ and IL 2 by mononuclear cells stimulated by PHA-P and a mutual reduction in IL4 and IL10. Consequently, there is a highly significant increase in the IFN $\gamma$-to-IL4 ratio compared with the control group. After THR, even when the prosthesis was stable, there was still an alteration in the immunological parameters which were analysed, and the type of prosthesis seemed to affect the behaviour of immune cells. In subjects with metal-onmetal couplings, and more so in those with metal-on-polyethylene couplings, the pattern of release of cytokines was similar to that observed in the pre-surgery group.

THR eliminates the severely damaged joint, but not the basic disease, and this may be why the expansion of type- 1 lymphocytes is also observed in the peripheral blood of patients with prostheses. Furthermore, with metal-on-metal and metal-on-polyethylene couplings there is also a significant depletion in the number of helper and cytotoxic T-lymphocytes, which could prevent the rebalancing of the type-1 and type- 2 subpopulations. In these patients the high levels of circulating chromium and cobalt could play a crucial role in causing the immunological changes. This interpretation seems to be confirmed by what was observed in patients with ceramic-on-ceramic couplings in whom the chromium and cobalt levels were normal. There was no significant reduction in the number of T-lymphocytes and the increase in type- 1 cytokines was balanced by a significant increase in type- 2 cytokines, so that the IFN $\gamma$ to IL4 ratio was similar to the control group. Maintaining a balance between the two subpopulations is important for the homeostasis of the immune system, because the cytokines produced by these cells have specific functions. In particular, they contribute to reciprocal adjustment.

Our study has shown that immunological changes may be related to the presence of the implant, but the question remains as to whether these abnormalities are able to compromise the defence mechanism against foreign organisms or deviant native cells. A moderate defect of the immune profile is not necessarily responsible for immediate adverse effects, because the immune system is flexible and is able to use alternative factors and mechanisms of compensation. Nevertheless, the data suggest some caution in considering the immune status of patients who have undergone THR, since the consequences of a chronic defect could become clinically evident in the long term. ${ }^{31}$

This research was supported by grants of the Italian Ministry of Health (Ricerca Corrente).

No benefits in any form have been received or will be received from a commercial party related directly or indirectly to the subject of this article.

\section{References}

1. National Institutes of Health Consensus Development Conference Statement. Total hip replacement. 1994;12:1-31.

2. Archibeck MJ, Jacobs JJ, Black J. Alternate bearing surfaces in total joint arthroplasty: biologic considerations. Clin Orthop 2000;379:1221.

3. Sieber HP, Rieker CB, Kottig P. Analysis of 118 second-generation metal-on-metal retrieved hip implants. J Bone Joint Surg [Br] 1999;81B:46-50. 
4. Bizot P, Nizard R, Hamadouche M, Hannouche D, Sedel L. Prevention of wear and osteolysis: alumina-on-alumina bearing. Clin Orthop 2001;393:85-93.

5. Dorr LD, Wan Z, Longjohn DB, Dubois B, Murken R. Total hip arthroplasty with use of the Metasul metal-on-metal articulation: four to seven-year results. J Bone Joint Surg [Am] 2000;82-A:789-98.

6. Garino JP. Modern ceramic-on-ceramic total hip systems in the United States: early results. Clin Orthop 2000;379:41-7.

7. Friberg L, Norberg GF, Kessler E, Vouk VB. Handbook on the toxicology of metals. Vol. 2. Amsterdam: Elsevier Science Publishers, 1986:194.

8. Granchi D, Ciapetti G, Savarino L, et al. Assessment of metal extract toxicity on human lymphocytes cultured in vitro. J Biomed Mater Res 1996;31:183-91.

9. Granchi D, Cenni E, Ciapetti G, Savarino L, Stea S, Gamberini S, Gori A, Pizzoferrato A. Cell death induced by metal ions: necrosis or apoptosis? J Mater Science: Materials in Medicine 1998;9:31-7.

10. LaIuppa JA, McAdams TA, Papoutsakis ET, Miller WM. Culture materials affect ex vivo expansion of hematopoietic progenitor cells. $J$ Biomed Mater Res 1997;36:347-59.

11. Savarino L, Granchi D, Ciapetti G, et al. Effects of metal ions on white blood cells of patients with failed total joint arthroplasties. $J$ Biomed Mater Res 1999;47:543-50.

12. Hallab N, Merritt K, Jacobs JJ. Metal sensitivity in patients with orthopaedic implants. J Bone Joint Surg [Am] 2001;83-A:428-36.

13. Granchi D, Ciapetti G, Savarino L, et al. Expression of the CD60 activation antigen on lymphocytes of patients with hip prosthesis. Biomaterials 2000;21:2059-65.

14. Granchi D, Verri E, Ciapetti G, et al. Bone-resorbing cytokines in serum of patients with aseptic loosening of hip prostheses. J Bone Joint Surg [Br] 1998;80-B:912-7.

15. Granchi D, Ciapetti G, Stea S, et al. Cytokine release in mononuclear cells of patients with Co-Cr hip prosthesis. Biomaterials 1999;20:1079 86.

16. Li TF, Santavirta $\mathbf{S}$, Waris V, et al. No lymphokines in T-cells around loosened hip prostheses. Acta Orthop Scand 2001;72:241-7.
17. Goodman SB, Huie P, Song Y, et al. Cellular profile and cytokine production at prosthetic interfaces: study of tissues retrieved from revised hip and knee replacements. J Bone Joint Surg [Br] 1998;80-B:531-9.

18. Boyum A. Isolation of mononuclear cells and granulocytes from human blood. Scand J Clin Invest 1968;97:77-89.

19. Craston R, Koh M, McDermott A, et al. Temporal dynamics of CD69 expression on lymphoid cells. J Immunol Methods 1997;209:37-45.

20. Savarino L, Granchi D, Ciapetti G, et al. Ion release in patients with metal-on-metal hip bearings in total joint replacement: a comparison with metal-on-polyethylene bearings. $J$ Biomed Mater Res 2002;63:467-74.

21. Mosmann TR, Sad S. The expanding universe of T-cell subsets: Th1, Th2 and more. Immunol Today 1996;17:138-46.

22. Sad S, Marcotte R, Mosmann TR. Cytokine-induced differentiation of precursor mouse CD8T cells into cytotoxic CD8T cells secreting Th1 or Th2 cytokines. Immunity 1995;2:271-9.

23. Granchi D, Verri E, Ciapetti G, et al. Effects of chromium extract on cytokine release by mononuclear cells. Biomaterials 1998;19:283-91.

24. Thorpe R. Interleukin-2. In: Mire-Sluis A, Thorpe R, eds. Cytokines Academic Press Inc. San Diego, 1998:19-33.

25. De Maeyer E, De Maeyer-Guignard J. Interferon gamma. In: Mire-Sluis A, Thorpe R, eds. Cytokines. Academic Press Inc. San Diego, 1998:391-400.

26. Mire-Sluis AR. Interleukin-4. In: Mire-Sluis $A$, Thorpe $R$, eds. Cytokines. Academic Press Inc. San Diego, 1998:53-68.

27. de Waal Malefy R. Interleukin-10. In: Mire-Sluis A, Thorpe R, eds Cytokines. Academic Press Inc. San Diego, 1998;5:151-67.

28. Liossis SN, Tsokos GC. Cellular immunity in osteoarthritis: novel concepts for an old disease. Clin Diagn Lab Immunol 1998;5:427-9.

29. Nakamura H, Yoshino S, Kato T, Tsuruha J, Nishioka K. T-cell mediated inflammatory pathway in osteoarthritis. Osteoarthritis Cartilage 1999;7:401-2.

30. Sakkas LI, Scanzello C, Johanson N, et al. T-cells and T-cell cytokine transcripts in the synovial membrane in patients with osteoarthritis. Clin Diagn Lab Immunol 1998;5:430-7.

31. Center for Devices and Radiological Health. Guidance for industry and FDA reviewers. Immunotoxicity Testing Guidance. 1999. 1-16. 